\title{
Covid-19 and Sustainable Tourism: Macroeconomic Effect and Policy Comparison among Europe, the USA and China
}

\author{
Mohammad Monirul Islam*, Farha Fatema \\ Assistant Professor, Department of International Business (IB), Faculty of Business Studies, University of Dhaka, BANGLADESH \\ *E-mail for correspondence: $\underline{\text { mmislam@du.ac.bd }}$
}

https://doi.org/10.18034/abr.v10i1.462

\begin{abstract}
This study examines the potential macroeconomic effects of Covid-19 on the tourism sector of Europe, the USA, and China as well as provides policy suggestions in light of previous scholarly works. The study finds that the global tourism sector is geocentric and the tourism sector of EU countries is interdependent. The study also finds strong domestic tourism in the USA and China whereas domestic tourism in EU countries is not that strong. As domestic tourism is less income-elastic than international tourism countries should promote domestic tourism to recover the loss of this sector from the adverse effect of Covid-19. Although the probable loss of the tourism sector can be estimated with reference to the recent previous global economic crises, the study assumes far-reaching and massive effects of Covid19 on the tourism sector due to strictly restricted or banned global and domestic travel as well as the unknown duration of the pandemic. The study also finds the similarity of age groups participating in tourism and infected and died by Covid-19. So, combined and comprehensive policies should be formulated to save the international tourism sector from the drastic catastrophe of Covid-19.
\end{abstract}

Key words: Covid-19, tourism sector, macroeconomic effects, domestic tourism, international tourism, global economic crises

\section{INTRODUCTION}

In recent times, the world is going through one of the toughest situations of the century due to the Covid-19 outbreak. It is an infectious disease caused by SARS Cov2 Virus. Although the virus was first identified in the Wuhan city of Hubei province of China where it infected 82,295 people causing the death of 3542 the deadly devastation of the virus is now visible in Europe and the USA which are now the center of the virus after the situation of China was improved. Most of the European countries have reported infections and deaths from Covid-19 and the situation is devastating in Italy, Spain, France, and the UK. The most catastrophe exits in the USA due to COvid-19 where the virus infected more than 1.18 million and caused the death of around 68,000 (source: https://www.worldometers.info/coronavirus/, access date $03 / 05 / 2020)$.

However, only the statistics of infected and deaths do not show the true devastating picture of Covid-19. The global economy is literally locked down for more than two months due to the outbreak. Although the economic activities of China, the epicenter of Covid-19 is improving the whole of Europe and the USA are almost totally locked down. The Covid-19 outbreak results in a massive and farreaching economic burden for the whole economics including the USA, China, and Europe (Barua, 2020). The functioning of global supply chains has disrupted and the world economy is experiencing a contraction in production. Limited and restricted transport has slowed down economic activities. Global financial markets are also experiencing a significant downturn. The Covid-19 outbreak presents profoundly serious threats to the stability of the global financial system, despite the forceful government and central banks' actions (McKibbin \& Fernando, 2020). The IMF predicted that the great lockdown recession would be the steepest in almost a century and warned that contraction and recovery of the world economy would be worse than anticipated if Covid19 outbreak longers or returns. The IMF estimated a global GDP shrink of 3\% this year, but much depends on the longevity of the pandemic, its effect on activity, and related stress in the financial and commodity market (IMF, 2020). As Covid-19 continues to spread around the 
world, it drastically affects the flow of goods and people as well as stall the global economies which may result in a global recession (Carlsson-Szlezak et al., 2020). di Mauro (2020) argued that a macroeconomic flu first results in lower output and then lead to rapid recapture to catch-up the shortfall. But the Covid-19 outbreak will last long that will cause large and persistent global disruption of production and consumption. According to Boone, Haugh, Pain, and Salins (2020), this pandemic will impact the global economy in three channels such as supply shock, demand shock, and uncertainty leading to reduced consumption of goods and services. As the outbreak is spreading sharply day by day the projection of the possible effect is difficult. Baldwin and Tomiura (2020) further added that both demand and supply shocks will substantially affect international trade in goods and services in the global market.

The outbreak of the pandemic possesses major and evolving challenges in the global tourism sector. The tourism sector plays a significant role in the global economy. It accounts for $10.3 \%$ of global GDP, creates 1 in 10 jobs around the world, and generates $6.8 \%$ of total exports (WTTC, 2019). However, the tourism sector experiences one of the hardest hits by the Covid-19 pandemic which affects both supply and demand side of the sector. The travel restriction and continuous lockdown of several countries and territories worsen the situation. According to (UNWTO, 2020). The Covid-19 pandemic may result in the decline of international tourist arrivals by $20 \%-30 \%$ which can translate into the US $\$ 30$ to $\$ 40$ billion. The loss in the tourism sector due to the pandemic could be much higher if the pandemic lasts longer. This downturn may accelerate the risk of weaker world economy, social, geographical, and trade tourism. So, this tourism sector demands special attention to rigorous research during the Covid-19 outbreak. Pallini (2020) reported that due to the travel ban, airspace closures, and low demand for travel almost 64 airlines stopped their flights. Restriction on air travel makes operating the flights impossible for the companies.

Table 1: Regional level contribution of the global tourism industry

\begin{tabular}{|c|c|c|c|}
\hline $\begin{array}{c}\text { Country } \\
\text { /region }\end{array}$ & $\begin{array}{c}\text { International } \\
\text { tourism receipts } \\
\text { (bn USD) }\end{array}$ & $\begin{array}{c}\text { \% of } \\
\text { world } \\
\text { tourism }\end{array}$ & Infected by \\
Covid-19* \\
\hline World & 1462 & 39 & $3,581,884$ \\
\hline Europe & 571 & 23 & $1,357,104$ \\
\hline Americas & 338 & 30 & 466,807 \\
\hline $\begin{array}{c}\text { Asia and the pacific } \\
\text { excluding China }\end{array}$ & 442 & 3 & 42778 \\
\hline Africa & 38 & 17.47 & $\mathbf{1 , 1 8 8 , 4 2 1}$ \\
\hline USA & 214.5 & $\begin{array}{l}10 \% \text { of Asia } \\
\& \text { the pacific }\end{array}$ & 83,961 \\
\hline China & 40.4 & & \\
\hline
\end{tabular}

*Source: https://www.worldometers.info/coronavirus/, and https://ourworldindata.org/grapher/total-covid-cases-region Access date 03/05/2020
Although Covid-19 was first identified in China, the hardest hit of the pandemic is seen in the USA followed by Europe, especially Spain, Italy, France, Germany, and the UK. These are the economies that constitute more than $90 \%$ share of the global tourism sector. Able 1 summarises the international tourism scenario. Europe constitutes 39\% of world tourism followed by Asia and the Pacific and America of $30 \%$ and $23 \%$ respectively. Among the Americas, the USA has a share of $63.5 \%$ of total tourism receipts whereas China comprises $10 \%$ of tourism receipts among Asia and the Pacific countries. It is clear from the above discussions that these are the economies that are severely affected by the Covid-19 pandemic and they are also the major Participants of global tourism sectors. Thus analyzing the tourism sector of these economies and the effect of Covid-19 on the tourism of these countries will provide real scenarios of Covid -19's impact on the world tourism industry of the major infected countries and provide necessary policy suggestions. The remainder of this study is arranged as follows. The next section comparatively analyses the economic effect of Covid-19 on the tourism industry of the selected countries. Section 3 makes a critical analysis of the Covid-19 and tourism sector's linkage. This section also provides suggestions based on scholarly articles. The final section makes concluding remarks.

\section{Covid-19 AND Tourism SeCtor-Economic EfFECT ANALYSIS}

The current and post effect of Covid-19 cane be huge unemployment. Pickert (2020) reported that during the Covid-19 pandemic the U.S. government received an unparalleled increase in the number of people applying for jobless benefits with a total of 3.28 million within March 21. Hutt (2020) also estimated that unemployment in the UK could rise by 2.1 million to 3.4 million due to this pandemic. The economic contribution of the tourism sector and the potential economic effect of the Covid-19 pandemic can be understood by the data provided in table 2. As per the data, tourism sectors arrange 26.587 million employment opportunities for Europe which is $11.17 \%$ of EU total employment. In the case of export, the tourism sector contributes $6.02 \%$ of the export of EU, which is almost US $\$ 512.39$ billion. The contribution of the tourism sector to GDP of the EU is $9.41 \%$ which is USD 1724.69 billion. The tourism sector also plays a similar importance to the US economy. The sector creates $10.66 \%$ of the total employment of the USA and contributes $8.57 \%$ to the country's GDP and $7.79 \%$ to the country's total export. 
Table 2: Covid-19 and Tourism- Economic analysis (2019)

\begin{tabular}{|l|c|c|c|c|c|c|}
\hline $\begin{array}{c}\text { Country/ } \\
\text { Region }\end{array}$ & $\begin{array}{c}\text { Total employment } \\
\text { (million) }\end{array}$ & $\begin{array}{c}\text { \% of } \\
\text { employment }\end{array}$ & $\begin{array}{c}\text { Contribution to GDP } \\
\text { (bn USD) }\end{array}$ & $\begin{array}{c}\text { \% of } \\
\text { GDP }\end{array}$ & $\begin{array}{c}\text { Tourism export } \\
\text { (bn USD) of }\end{array}$ & $\begin{array}{c}\text { \% } \\
\text { total export }\end{array}$ \\
\hline EU & 26.587 & 11.1732 & 1724.69 & 9.41931 & 512.39 & 6.0241 \\
\hline USA & 16.826 & 10.6651 & 1839.03 & 8.57376 & 195.12 & 7.7939 \\
\hline China & 35.103 & 4.44537 & 3017.01 & 12.897 & 178.96 & 4.8146 \\
\hline France & 2.678 & 9.43439 & 229.252 & 8.49816 & 65.358 & 7.7204 \\
\hline Germany & 3.154 & 6.97141 & 346.626 & 9.05771 & 52.391 & 2.9108 \\
\hline Italy & 1.719 & 7.36344 & 259.74 & 13.0473 & 50.12 & 7.9023 \\
\hline Spain & 1.043 & 5.28322 & 197.774 & 14.2848 & 86.773 & 18.003 \\
\hline UK & 1.634 & 4.58217 & 254.039 & 9.02489 & 35.8484 & 4.22603 \\
\hline Netherlands & 0.443 & 5.65039 & 51.0281 & 5.65319 & 21.554 & 2.8798 \\
\hline Sweden & 0.188 & 3.65989 & 43.2106 & 8.17245 & 17.115 & 6.8503 \\
\hline Switzerland & 0.179 & 3.51386 & 53.0869 & 7.59387 & 20.076 & 5.0679 \\
\hline Turkey & 0.855 & 3.05337 & 84.8699 & 11.274 & 41.426 & 17.507 \\
\hline
\end{tabular}

Source: World travel and tourism council (https:// www.wttc.org/datagateway/)

The contribution of this sector to China is $12.89 \%$ which is the maximum in number as well as a percentage compared to its contribution to the GDP of the EU and the USA. Although the share of tourism in employment and export of China does not have high importance in percentage the contribution is noteworthy especially in employment in number where the tourism sector creates 35.10 million jobs for the Chinese people. The above scenario can easily help to assume the potential economic effect of the Covid-19 pandemic. As almost the whole world is locked down due to the pandemic, the global economy will experience a drastic negative impact. A large population in the USA, the EU, and China will lose their job, the economy will lose huge amounts of GDP and export income contributed by the tourism sector due to the ban and restriction of travel within and between countries for the pandemic. Moreover, it is not still confirmed that when the pandemic will end and the situation becomes normal. The longer the pandemic will continue, the higher economic loss will occur. The individual analysis of the major European countries highly infected by the Covid-19 provides deeper insight into the Covid-19 and economic loss linkage resulting from the collapse of the tourism sector. Among the EU countries, Italy, Spain, France, Germany, and the UK are highly infected by Covid-19 and the tourism sector plays a significant role in these economies compared to others. Spain gets $14.28 \%$ of GDP and $18 \%$ of export income from the tourism sector whereas $7.36 \%$ of total employment in Spain is created by this sector. The tourism sector is also similarly important for Italy as the sector contributes $13.04 \%$ to GDP and $7.90 \%$ to total export. The tourism sector also creates a considerable share of employment opportunities for these economies with a high share in France and Italy. Among other EU countries, tourism has a significant contribution to GDP and export in Turkey.

Undoubtedly, after the USA, European countries more specifically, Italy, Spain, France, UK, and Germany experience the deadliest catastrophe of the Covid-19 pandemic. At the same time, tourism plays a significant role in economies. So it is evident that the Covid-19 outbreak will critically affect the sustainability of the tourism sector in countries that subsequently affect the economy as a whole. As the end of the pandemic is unknown, the situation of the tourism sector and the economy of these countries will be more critical if the pandemic lasts longer. Other issues such as income effect, sources of tourist export, demographic analysis of tourists, and so on can substantially explain the above scenarios more insightfully. The next section serves this purpose.

\section{Covid-19 \& TOURISM SECTOR-A CRITICAL SYNTHESIS}

According to Gopinath (2020), the economic effects of the Covid-19 pandemic are already evident in the most affected countries and the impacts are larger in the service industries due to social distancing which can be contrasted with the global recession. Table 3 briefly summarizes the international tourist arrivals of the countries from different regions. It is obvious from the data that international tourism is geocentric. In the USA $61 \%$ of arrivals are from American countries and only $20 \%$ are from Europe whereas $93 \%$ of international tourist arrivals in China are from Asia and the Pacific, and a negligible share of international tourists visits China from other regions. However, the structure of international tourism in Europe is critical. The tourism exports of the EU countries are interdependent. Almost three-fourth (75\%) of the international tourists of the EU countries except Switzerland come from the EU region. This interdependency of the tourism industry of EU countries may accelerate or even intensify the effects of the Covid-19 pandemic on the whole EU tourism industry. More importantly, the tourism export of EU countries will be drastically affected by the pandemic due to the high share of international tourists coming from the EU regions. This finding is supported by Cao, Li, and Song (2017) who identified the co-movements of tourism demand. They found that a negative shock of China's real income and tourism price results in fluctuation in tourism demand of its partner countries in the short run. In the long run, China and its neighbouring countries are more negatively affected than developed countries. 
Table 3: International Tourist arrivals by region of origin ( $\%$ share)

\begin{tabular}{|l|c|c|c|c|c|}
\hline \multirow{2}{*}{ Country/Region } & \multicolumn{5}{|c|}{ International arrivals by region of origin (\% share) } \\
\cline { 2 - 6 } & Europe & Americas & Asia and the pacific & Africa & Middle east \\
\hline EU & 51 & 25 & 15 & 5 & 4 \\
\hline USA & 20 & 61 & 17 & 1 & 1 \\
\hline China & 2 & 4 & 93 & 0 & 0 \\
\hline France & 78 & 10 & 7 & 3 & 2 \\
\hline Germany & 76 & 11 & 11 & 0 & 0 \\
\hline Italy & 89 & 8 & 3 & 1 & 0 \\
\hline Netherlands & 80 & 11 & 8 & 1 & 1 \\
\hline Spain & 87 & 8 & 3 & 0 & 0 \\
\hline Sweden & 83 & 8 & 8 & 1 & 0 \\
\hline Switzerland & 57 & 29 & 13 & 2 & 2 \\
\hline Turkey & 75 & 11 & 9 & 2 & 1 \\
\hline UK & 72 & 15 & 9 & & 2 \\
\hline
\end{tabular}

Source: World travel and tourism council (https://www.wttc.org/datagateway/)

Table 4 represents the sources of the tourism revenue and provide insight regarding the tourism industry of Europe, the USA, and China. It is evident from the data that the revenue from leisure tourism is substantially higher than that of business. It indicates that people from all over the world visit foreign countries mostly for leisure. As C0vid-19 significantly affects the income and employment of the people, its effect on the tourism industry will be drastic as the tourism industry is specifically a leisure activity.

Table 4: Sources of Revenue from Tourism

\begin{tabular}{|c|c|c|c|c|}
\hline Country/Region & $\begin{array}{c}\text { Business Tourism } \\
\text { (bn USD) }\end{array}$ & $\begin{array}{c}\text { Leisure Tourism } \\
\text { (bn USD) }\end{array}$ & $\begin{array}{c}\text { Domestic tourism } \\
\text { (bn USD) }\end{array}$ & $\begin{array}{c}\text { Tourism export } \\
\text { (bn USD) }\end{array}$ \\
\hline EU & 309.133 & 1192.34 & 989.081 & 512.39 \\
\hline USA & 354.317 & 836.746 & 995.943 & 195.12 \\
\hline China & 179.443 & 780.394 & 1636.83 & 65.96 \\
\hline France & 37.2968 & 154.177 & 126.116 & 52.391 \\
\hline Germany & 62.9668 & 299.597 & 310.172 & 50.12 \\
\hline Italy & 40.0455 & 166.726 & 156.652 & 86.773 \\
\hline Netherlands & 11.6358 & 30.1903 & 67.9388 & 21.84 \\
\hline Spain & 17.3193 & 137.393 & 169.09 & 17.115 \\
\hline Sweden & 12.7107 & 25.6558 & 20.2722 & 20.076 \\
\hline Switzerland & 7.45775 & 38.51 & 21.2515 & \\
\hline Turkey & 8.81406 & 55.7699 & 25.8915 & 41.426 \\
\hline UK & 68.3129 & 136.625 & 23.1583 & \\
\hline
\end{tabular}

Source: World travel and tourism council (https://www.wttc.org/datagateway/)

The result is supported by Yang et al. (2020). They identified that an increase in health disaster risks declines the health status of the people which consequently leads to lower tourism and generic output. Hall and Jones (2007) argued that households obtain utility from consumption and health status where consumption is distributed between tourism goods and generic goods. Health status is subject to disastrous risk during an epidemic (WHO, 2018). If a disaster arises, the households raise health expenditure to rebuild and accumulate health which in turn reduces leisure spending (Yagihashi \& Du, 2015). The data indicate that domestic tourism revenue is substantially higher than tourism export in China and the USA. Although domestic tourism of the EU countries altogether is higher than the tourism export country-specific data shows that domestic tourism is not much higher than tourism export compared to the USA and China. Due to the significant negative shock of Covid-19 on health risks and household income countries should promote domestic tourism. According to Eugenio-Martin and Campos-Soria (2011), tourism demand is income elastic. Substantial differences exist in the income elasticity's of the probability of domestic travel or traveling abroad. Domestic travel is less income elastic than traveling abroad. 


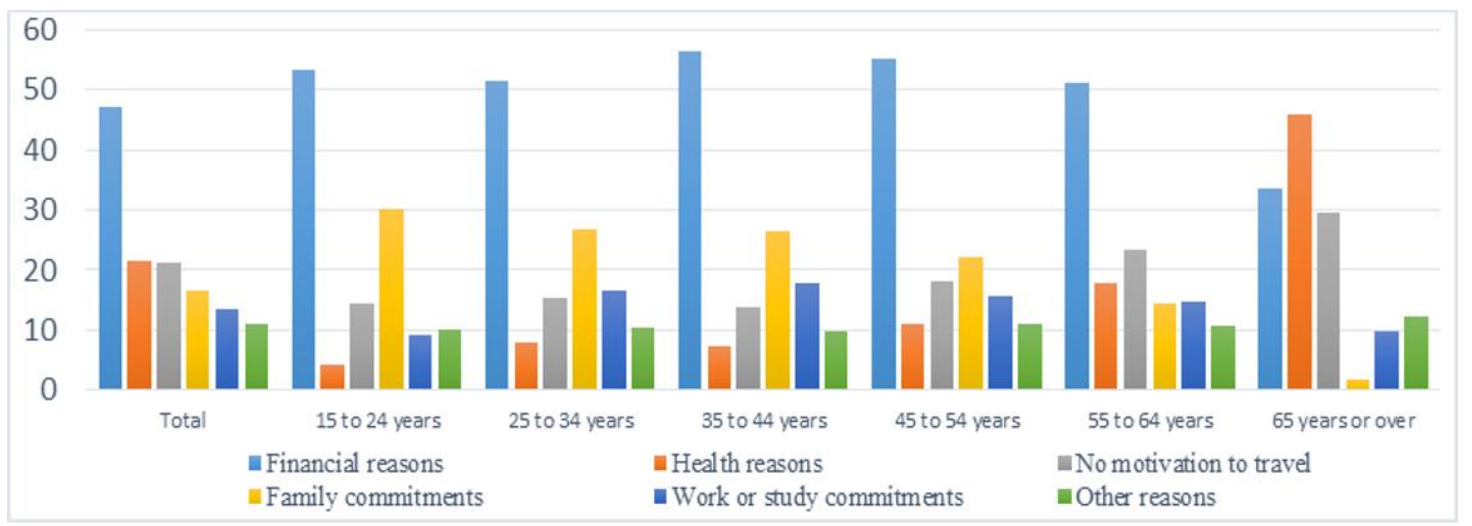

Graph 1: Main reasons reported for not participating in tourism by age group, EU-27 (\%)

Source: Eurostat (online data codes: tour_dem_npage, demo_pjangroup) Percentages do not add up to 100\% due to multiple answers possibility.

The importance of financial issues in tourism is further clarified by the Eurostat data shown in graph 1 . The graph shows that almost $50 \%$ of the people of different age groups except for the age group of $65+$ explain financial issues as the major reason for not participating in tourism either domestic or abroad. The second most reason for not participating in tourism varies among the age groups. People over 65 recognized health issues as the most significant reasons for not participating in tourism followed by financial reasons.

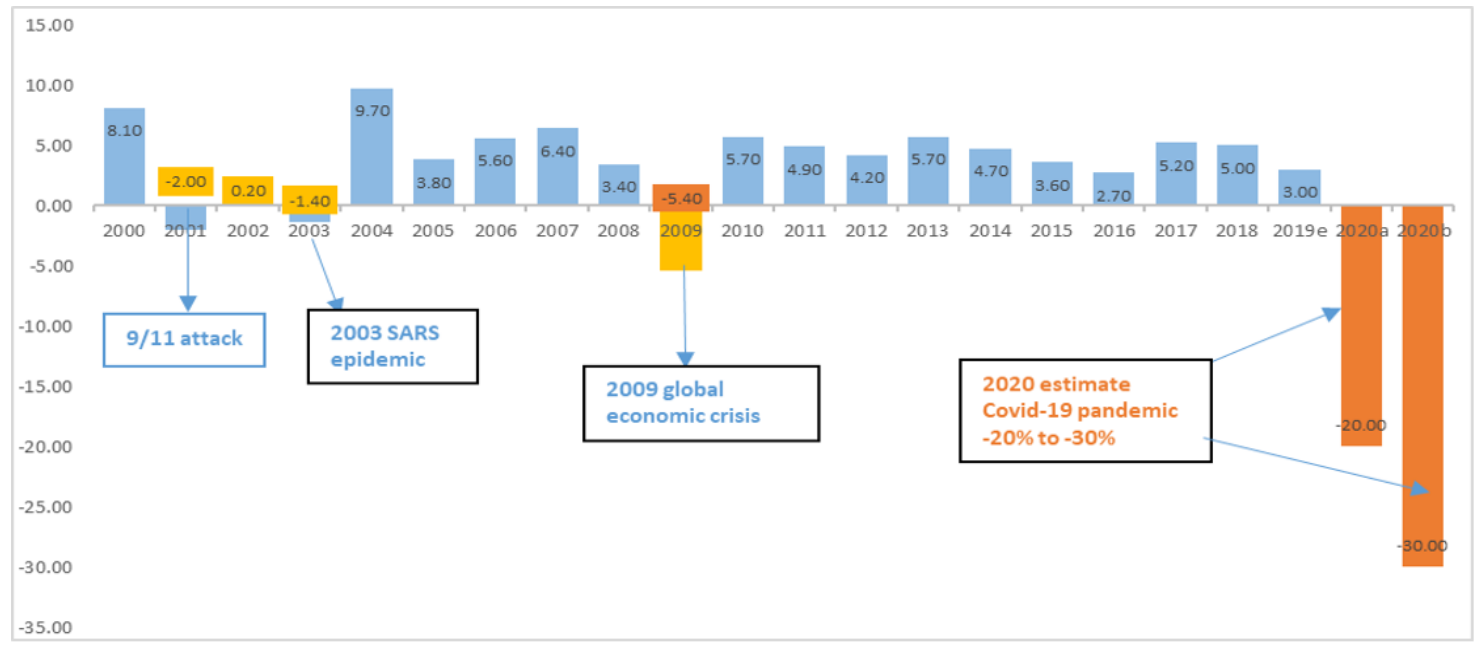

Graph 2: 2020 forecast international tourist receipts, world (\% change) and

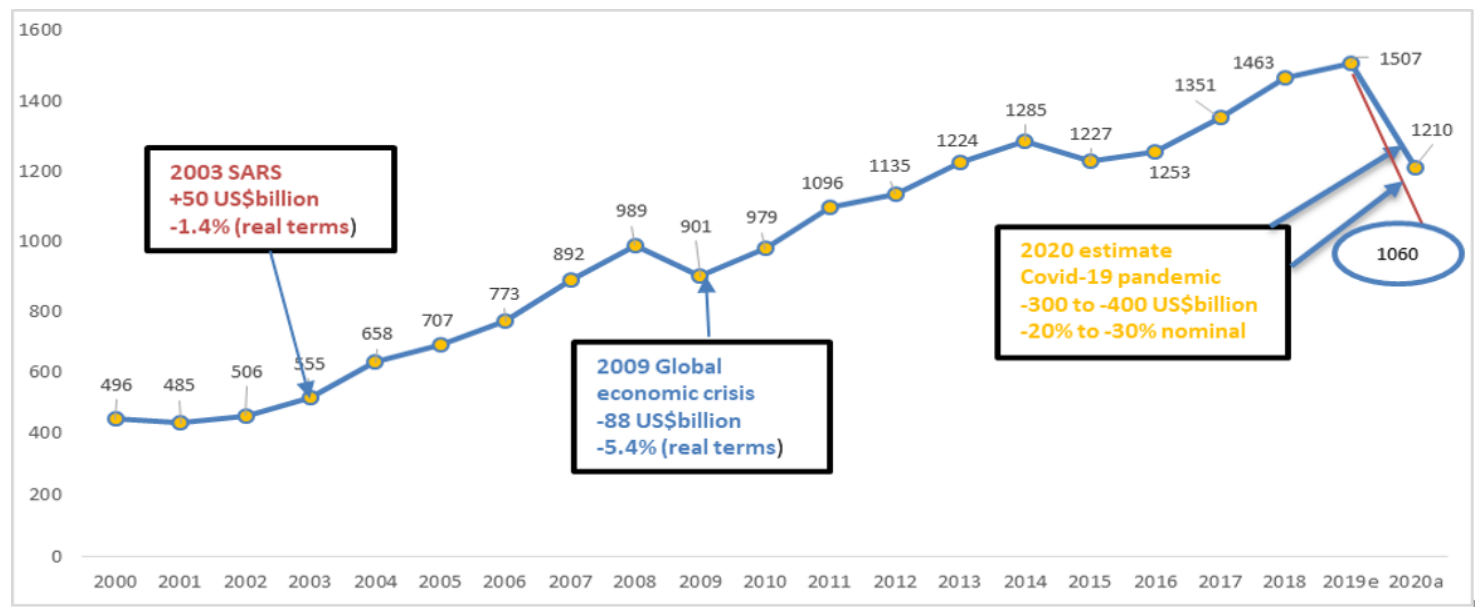

Graph 3: 2020 forecast international tourism receipts, world (US\$ billion)

Source: UNWTO. (2020). Impact assessment of the COVID 19 outbreak on international tourism. March 24, 2020 
UNWTO (2020) estimated the probable economic losses in the tourism sector due to Covid-19 with a cautious reference to previous global economic crises such as SARS 2003 and global economic recession 2009. As per their estimates on March 24, international tourist arrivals could decline by $20 \%$ to $30 \%$ in 2020 , which would translate into a loss of US $\$ 300 \mathrm{~b}$ to US\$450 international tourism receipts. However, Covid-19 pandemic is not like other global crises. According to McKibbin and Fernando (2020), we live in a very different world compared to those global crises faced before. Combined and interlinked demand and supply shock in the global economy will deepen the negative shocks. Thus the potential negative impacts of the Covid-19 pandemic are much higher and stronger than any other crisis experiences in this history. According to Tooze (2020), the global crisis resulting from Covid-19 will mush more drastic than the 2008 global crisis. He termed the last 2008 global economic crisis as financial heart attack whereas the economic crisis resulting from this pandemic is a full-body seizure. ElErian (2020) also argued that the global economy into recession due to the Covid-19 outbreak which will be sudden and sharp. According to Milliken (2020), the economy of the UK is dwindling at a high leap that is faster than during the 2008-09 financial crisis because of the closedown of the service sector during the Covid-19 outbreak. Other arguments help understand the catastrophic effect of Ocvid-19 on tourism compared to the recent two global crises. The whole world is literally locked down since the beginning of 2020. Travel between and within countries is banned or if allowed are highly restricted. It is almost at the end of April still there is no sign that the pandemic will end. The monthly international tourist arrival curve shows that May to September is the peak time for global tourist arrival. So if pandemic lasts longer and travel restriction continues, the impact of Covid-19 on tourism will be highly catastrophic.

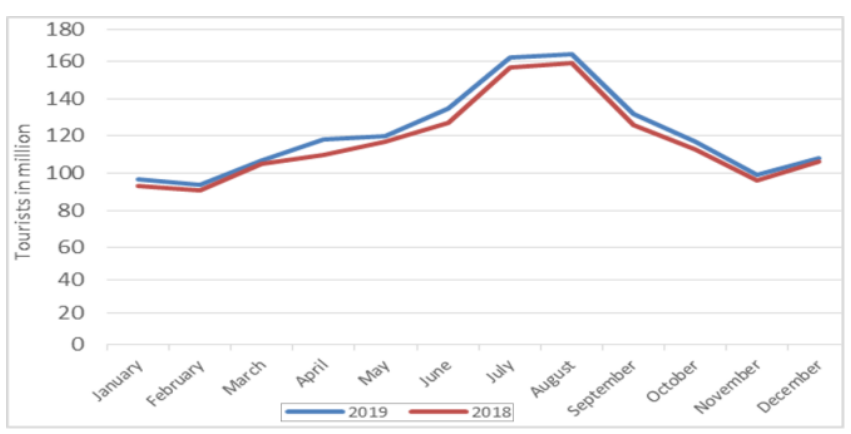

Graph 4: Monthly international tourist arrivals

Another critical factor of the effect of Covid-19 on tourism is the demographic characteristics of people during by Covid-19 and people participating in tourism. For example, data on the age group of the population participating in tourism shows that people aged $45+$ years constitute more than $50 \%$ of the total population participating in tourism in the EU. The infected and death from Covid-19 has coincided scenarios. According to Surveillances (2020), a high majority of the people (93.74\%) died for Covid-19 aged between 50 years and onward. Thus there is a hidden negative shock of Covid19 on international tourism.

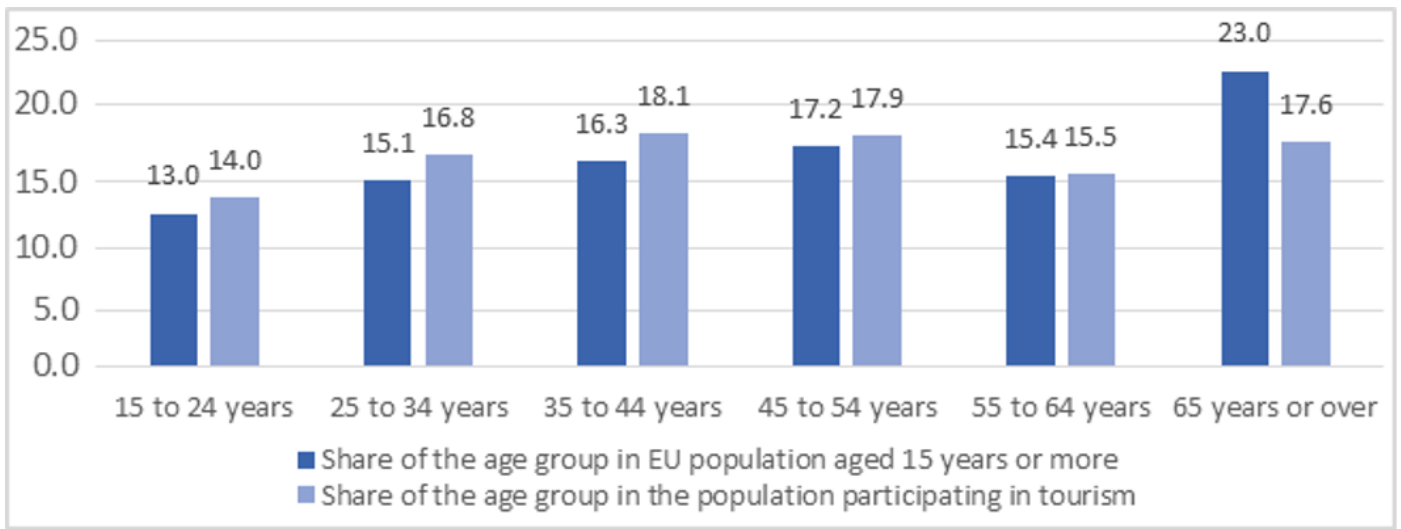

Graph 5: Share of the EU population participating in tourism, by age groups, EU-28

Source: Eurostat (online data codes: tour_dem_toage, demo_pjangroup)

\section{Discussion AND ConClusions}

The world is passing its most critical time in the history of the last decade. The Covid-19 outbreak has locked down the countries as well as the whole world. Ban and some cases of restricted travel within and between countries make global economic activities stagnant for more than three months. Oil prices turned into negative which did not happen in history. The pandemic has infected more than 2.5 million people and caused the death of around 200,000 people around the world. Still WHO announced that the world did not see the deadliest impact of Covid19 and the worse situation is waiting. Global economic activities are almost constant, and it is assumed by the economist that the global economy will face the worst recession after the pandemic. It will upsurge the number of people living under the poverty line. The effect of the pandemic will be more deadly if it lasts longer. 
It is widely recognized that tourism is mostly leisure activity. As Covid-19 will negatively affect the employment and income of the people, the tourism industry will experience one of the hardest hits of the pandemic and the sustainability of tourism will be questioned. The USA, China, and EU countries such as Italy, Spain, Germany, France, and the UK face the worse hits of Covid-19. Moreover, the tourism sector plays a critical role in the economic activities of these countries. Thus identifying the possible effects of Covid-19 on the tourism sector of these countries demands significant research focus. It will also provide important policy suggestions for the global tourism industry. So, the purpose of this study is to examine the potential effect of Covid-19 on the tourism sector of the above-mentioned economies and provide policy suggestions in light of previous scholarly works. The study also provides policy suggestions for global tourism.

The study results suggest that the tourism sector has major contributions to employment, GDP, and export of the countries more importantly for the EU countries. The global tourism is geocentric. People prefer to visit within the region they belong to. The tourism industry of the EU countries as highly interdependent. Almost $75 \%$ of international tourist arrivals of the selected EU countries are European. So the effect of Covid-19 on the EU tourism sector can be multiplied. Combined and comprehensive policies should be formulated to save the tourism sector of the EU from the drastic catastrophe of Covid-19. The results also indicate that domestic tourism revenue is significantly higher than tourism export in China and the USA but this difference is not that high in the EU countries. As scholarly researches suggest that domestic tourism is less income elastic than tourism abroad, the countries can promote domestic tourism during the recession period comparing with the two recent global crisis SARS and 2009 recession. IMF estimated a probable decline of $20 \%$ to $30 \%$ in the tourism sector which is equivalent to 300-400 billion USD. This pandemic cannot be compared with the two previous global crises because the duration of the pandemic is still unknown, and it is not still high time to estimate the probable loss from the pandemic. Finally, people aged 50+ are most vulnerable to Covid-19 constituting 90\% of death from this infectious disease. At the same time more than $50 \%$ of the population participating in tourism aged $45+$ years. So proper initiative should be taken to reshape the tourism sector, more importantly for Europe. The availability of detailed data on Covid-19 as well as tourism data confined the analysis of the study. Further data availability can help rigorous research on this topic.

\section{REFERENCES}

Baldwin, R., \& Tomiura, E. (2020). Thinking ahead about the trade impact of COVID-19. In R. Baldwin \& B. W. di Mauro (Eds.), Economics in the Time of COVID-19: A VoxEU.org Book, Centre for Economic Policy Research, London.
Barua, S. (2020). Understanding Coronanomics: The economic implications of the coronavirus (COVID-19) pandemic. MPRA Paper No. 99693, Online at https://mpra.ub.unimuenchen.de/99693/.

Boone, L., Haugh, D., Pain, N., \& Salins, V. (2020). Tackling the fallout from COVID-19. In R. Baldwin \& B. W. di Mauro (Eds.), Economics in the Time of COVID-19: A VoxEU.org Book, Centre for Economic Policy Research, London.

Cao, Z., Li, G., \& Song, H. (2017). Modelling the interdependence of tourism demand: The global vector autoregressive approach. Annals of Tourism Research, 67, 1-13.

Carlsson-Szlezak, P., Reeves, M., \& Swartz, P. (2020). Understanding the economic shock of coronavirus. Harvard Business Review, Accessed 29 March 2020 at: https://hbr.org/2020/03/understanding-the-economic-shock-ofcoronavirus.

di Mauro, B. W. (2020). Macroeconomics of the flu. In "', Baldwin Weder di Mauro. In R. Baldwin \& B. W. di Mauro (Eds.), Economics in the Time of COVID-19: A VoxEU.org Book, Centre for Economic Policy Research, London.

El-Erian, M. (2020). The Coming Coronavirus Recession and the Uncharted Territory Beyond. Foreign Affairs, Accessed 27 March 2020

(https: / / www.foreignaffairs.com/articles/2020-0317 /coming-coronavirus-recession).

Eugenio-Martin, J. L., \& Campos-Soria, J. A. (2011). Income and the substitution pattern between domestic and international tourism demand. Applied Economics, 43(20), 2519-2531.

Gopinath, G. (2020). Limiting the economic fallout of the coronavirus with large targeted policies. In R. Baldwin \& B. W. di Mauro (Eds.), Mitigating the COVID Economic Crisis: Act Fast and Do Whatever: A VoxEU.org Book, Centre for Economic Policy Research, London.

Hall, R. E., \& Jones, C. I. (2007). The value of life and the rise in health spending. The quarterly journal of economics, 122(1), 3972 .

Hutt, R. (2020). The economic effects of COVID-19 around the world. World Economic Forum. Accessed 22 March 2020 at: https://www.weforum.org/agenda/2020/02/coronaviruseconomic-effects-global-economy-trade-travel/.

IMF. (2020). World Economic Outlook Chapter 1: The Great Lockdown (https://www.imf.org/en/Publications/WEO/Isues/2020 /2004/2014/weo-april-2020).

McKibbin, W. J., \& Fernando, R. (2020). The global macroeconomic impacts of COVID-19. In R. Baldwin \& B. W. di Mauro (Eds.), Economics in the Time of COVID-19.: A VoxEU.org Book, Centre for Economic Policy Research, London.

Milliken, D. (2020). Coronavirus hits UK economy with unprecedented force. Reuters, Accessed 26 Match 2020 at:(https:/ / www.reuters.com/article/us-britain-economypmi/coronavirus-hits-uk-economy-with-unprecedentedforce-idUSKBN21B14A).

Pallini, T. (2020). 64 global airlines have completely stopped flying scheduled flights due to travel bans, airspace closures, and low demand for travel - see the full list. Business Insider, Accessed April 1, 2020 at: (https://www.businessinsider.com/coronavirus-globalairlines-stopping-flights-suspending-operations-2020-3). 
Pickert, R. (2020). U.S. Jobless Claims Jump to 3.28 Million, Quadruple Prior Record. Bloomberg, Accessed 28 March 2020 (https:/ /www.bloomberg.com/ news/ articles/2020-03-26/ us-jobless-claims-surged-to-record-3-28-million-last-week).

Surveillances, V. (2020). The epidemiological characteristics of an outbreak of 2019 novel coronavirus diseases (COVID-19)China, 2020. China CDC Weekly, 2(8), 113-122.

Tooze, A. (2020). Is the Coronavirus Crash Worse Than the 2008 Financial Crisis. Foreign Policy, (https:/ / foreignpolicy.com/2020/03/18/coronaviruseconomic-crash-2008-financial-crisis-worse/).

UNWTO. (2020). Impact assessment of the COVID 19 outbreak on international tourism. March 24, 2020, https://webunwto.s3.eu-west-1.amazonaws.com/s3fspublic/2020-03/24-03Coronavirus.pdf.
WHO. (2018). Managing epidemics: key facts about major deadly diseases:

https://www.who.int/emergencies/diseases/managingepidemics-interactive.pdf.

WTTC. (2019). Economic Impact Report. https://wttc.org/enus/Research/Economic-Impact.

Yagihashi, T., \& Du, J. (2015). Health care inflation and its implications for monetary policy. Economic Inquiry, 53(3), 1556-1579.

Yang, Y., Zhang, H., \& Chen, X. (2020). Coronavirus pandemic and tourism: Dynamic stochastic general equilibrium modeling of infectious disease outbreak. Annals of Tourism Research, forthcoming.

$--0--$

Online Archive: https://abc.us.org/ojs/index.php/abr/issue/archive 